\title{
MAKNA BUDAYA LEKSIKON "MIZU" YANG TERCERMIN DALAM PERIBAHASA JEPANG DAN PADANANNYA DALAM PERIBAHASA SUNDA
}

\author{
Nani Sunarni ${ }^{1}$, Jonjon Johana ${ }^{2}$ \\ Fakultas Ilmu Budaya, Universitas Padjajaran \\ nani.sunarni@unpad.ac.id, jonjon.johana@unpad.ac.id
}

\begin{abstract}
This study aims to describe the meaning of the culture of mizu 'air' in Japanese proverbs and its equivalent in Sundanese proverbs. Data used in the form of Japanese proverbs related to water as much as 11 data. Data were analyzed using ethnolinguistic studies.

Based on the results of data analysis, structurally are identified four types. Namely data that is structured in pairs, contradictions, poems, and comparisons. The analysis shows that mizu 'air' is a substance that cannot be separated from human life, including Japanese and Sundanese people. Therefore, the mizu 'air' lexicon has a viewpoint for Japanese society that manifests itself in its speech. The analysis results identified that mizu 'air' has cultural meanings that indicate the nature or character of the water symbol.
\end{abstract}

Keywords: Japanese, mizu, cultural meanings, proverbs, Sundanese 


\section{ABSTRAK}

Penelitian ini bertujuan untuk mendeskripsikan makna budaya mizu 'air' dalam peribahasa Jepang dan padanannya dalam peribahasa bahasa Sunda. Data yang digunakan berupa peribahasa Jepang yang terkait dengan air sebanyak 11 data. Data dianalisis dengan menggunakan kajian etnolinguistik. Berdasarkan hasil analisis data, secara struktur teridentifikasi empat jenis data, yaitu data yang berstruktur berpasangan, kontradiktif, bersajak, dan perbandingan. Hasil analisis menunjukkan bahwa mizu 'air' merupakan zat yang tidak dapat dipisahkan dari kehidupan manusia di antaranya masyarakat Jepang dan Sunda. Oleh karena itu, leksikon mizu 'air' memiliki nilai pandang bagi masyarakat Jepang sehingga terwujud dalam peribahasanya. Hasil analisis teridentifikasi bahwa mizu 'air' memiliki makna budaya yang menunjukkan sifat atau karakter dari symbol air tersebut.

Kata kunci: Jepang, mizu, makna budaya, peribahasa, Sunda

\section{A. Latar Belakang}

Air ada yang turun dari langit dan ada pula yang keluar dari perut bumi kedua-duanya sangat bermanfaat bagi seluruh kehidupan baik manusia, hewan, maupun tanaman. Benda ini dalam bahasa Sunda disebut cai atau ci, dalam bahasa Jawa disebut banyu, dalam bahasa Inggris water, dalam bahasa Jepang disebut mizu, dan masih banyak lagi sebutan lain dalam bahasa-bahasa yang berbeda di dunia ini. Tidak ada satu pun kelompok masyarakat bahasa yang tidak memiliki nama untuk benda cair ini. Hal ini disebabkan semua makhluk yang ada di bumi tidak akan dapat hidup tanpa air. Oleh karena itu, tidak ada satu makhluk pun yang di dalamnya tidak memiliki zat yang disebut air atau cairan. Manusia sangat bergantung pada air. Air merupakan bagian daripada bumi yang menjadi sumber penghidupan makhluknya. Tiga perempat bumi diliputi air dan seperempatnya berupa daratan. Kebergantungan manusia terhadap air, dapat dibuktikan ketika pada 
zaman dahulu manusia hidup nomaden, mereka berkumpul dan hidup di mana air berada dan membentuk suatu permukiman. Oleh karena itu,dalam budaya Sunda, banyak ditemukan nama tempat yang dinamai atau diawali dengan dengan kata cai (ci) 'air', seperti Cibiru, Cijambu, Cigodeg, Cilimus dll. Selain itu, dalam budaya lain seperti budaya Jawa terdapat kata seperti Banyuwangi, Banyuasin dan lain-lain. Bahkan, dalam masyarakat di luar Indonesia pun seperti Jepang kata air 'mizu' banyak ditemukan dalam penggunaan nama orang seperti Mizuno, Shimizu, Mizutani, Mizuhou dan lain-lain.

Kedekatan air dalam kehidupan nmasyarakat baik masyarakat Sunda maupun Jepang, hal ini menjadi pengalaman hidup masingmasing masyarakat tersebut. Pengalaman hidup tersebut sangat mempengaruhi pola pemikirannya. Salah satu pola pemikirannya terwujud dalam budaya bahasa yaitu peribahasa. Setiap bangsa mempunyai peribahasa yang mencerminkan watak sesuatu bangsa itu. Hal ini disebabkan peribahasa menggambarkan pandangan dunia masyarakat atau bangsa yang mendukungnya. Bahkan sekaligus menyatakan pengalaman hidupyang telah dilalui serta corak kehidupan sesuatu bangsa secara keseluruhan. Dengan demikian, isi dan tema peribahasa yang dibicarakan atau disifatkan sebagai cerminan pandangan dunia serta etos nilai masyarakat pemilik peribahasa tersebut. Sama hal nya dengan peribahasa yang mengandung kata cai atau mizu dalam bahasa Sunda dan bahasa Jepang. Berdasarkan pengertian menurut Kamus Besar Bahasa Indonesia (KBBI, 1995:775) peribahasa adalah:(1) Kelompok kata atau kalimat yang tetap susunannya, biasanya mengiaskan maksud tertentu (dalam peribahasa termasuk juga bidal, ungkapan, perumpamaan); (2) Ungkapan atau kalimat ringkas padat, berisi perbandingan, perumpamaan, nasihat, prinsip hidup atau aturan tingkah laku.

Dalam Bahasa Jepang peribahasa disebut kotowaza. Menurut para ahli bahasa Jepang diantaranya disebutkan bahwa kotowaza adalah 
ungkapan pendek yang sejak dahulu kala diungkapkan secara luas di dalam masyarakat yang isinya berupa nasihat atau petuah, sindiran dan sebagainya ( Nihongo Daijiten, 1989: 160). Sementara di dalam Kamus Data Bangsa Jepang (Nihon Minzoku Shiryou Jiten,1989: 185) disebutkan bahwa peribahasa merupakan satu rangkuman kata-kata sederhana namun sangat tepat untuk membuat lawan bicara paham atau menyerah. Di pihak lain, dalam buku Penelitian Peribahasa (Kotowaza no Kenkyuu,2007:198) karya Fujii Otoo disebutkan bahwa kotowaza yaitu perilaku bahasa terhadap suatu perbuatan. Kemudian, Yanagida Kunio dalam bukunya Kamus Etnologi (Minzokugaku Jiten,1980:145) mengatakan bahwa kotowaza adalah teknik berbahasa, makna teknik berbahasa.

Pendapat lain dalam Ensiklopedia Dunia (Sekai Daihyakka Jiten,1981), Daitou Tokihiko pada kata entri kotowaza disebutkan bahwa berdasarkan fungsinya kotowaza memiliki empat kelompok yaitu kougekiteki kotowaza (peribahasa yang bersifat menyerang), keikenteki kotowaza (peribahasa empiris), kyoukunteki kotowaza (peribahasa yang berisi nasihat atau petuah), dan yuugiteki kotowaza (peribahasa yang bersifat permainan). Berdasarkan fungsinya tersebut dapat diklasifikasikan menjadi tiga jenis yaitu peribahasa yang bersifat kritikan (ironi atau sinisme), peribahasa yang bersifat nasihat, dan peribahasa yang bersifat hiburan. Selain itu, secara bentuk peribahasa Jepang memiliki berbagai ragam yaitu berupa deretan nomina, berpasangan, perbandingan, kontradiktif, angka, dan bersajak. Dalam bahasa Sunda peribahasa sepadan dengan kata paribasa. Danadibrata ( 2015:90) menjelaskan bahwa paribasa adalah basa anu digambarkeun supaya leuwih tetela kahartina jeung bedana karasa jauhna, nepi ka lamun kadenge saliwat asa pamohalan.'Peribahasa adalah bahasa yang digambarkan agar maksudnya lebih jelas dan perbedaannya, sehingga apabila terdengar sepintas terasa sesuatu yang tidak mungkin'. Lahirnya peribahasa berkaitan erat dengan aspek-aspek kehidupan 
masyarakat dalam berinteraksi antara dirinya, Tuhan, sesama individu, lingkungan, dan alam sekitarnya. Dalam penggunaannya, peribahasa memiliki posisi sangat penting karena berfungsi untuk (1) menegaskan makna dalam bertutur sehingga proses komunikasi menjadi lebih efektif; (2) memberikan efek kelembutan pada gaya bertutur (eufemisme) sehingga lebih menyentuh pikiran lawan bicara tanpa menyakiti perasaannya; (3) memberikan pengaruh (sugesti) kepada lawan bicara untuk berpikir lebih dalam sehingga dapat memaknai ungkapan tersebut dan bertindak lebih bijak.

Dengan tidak dapat dipisahkannya air dengan kehidupan manusia, maka leksikon air menjadi dasar ide atau gagasan terwujudnya kearifan lokal yang berupa peribahasa. Khususnya dalam peribahasa Jepang maupun peribahasa Sunda. Wiyadi dkk., 1995:755 menyebutkan bahwa peribahasa merupakan ungkapan atau kalimat-kalimat ringkas padat, yang berisi perbandingan, perumpamaan, nasihat, prinsip hidup atau aturan tingkah laku. Berdasarkan definisi di atas, bahwa peribahasa sebagai prinsip hidup berarti bagaimana "leksikon mizu atau air dipandang oleh masyarakat Jepang dan masyarakat Sunda.Kedua leksikon di atas, dalam penelitian ini termasuk leksikon hidrografis. Istilah hidrografis terdiri atas dua morfem yaitu morfem \{hidro\} dan \{grafis\}.Morfem \{hidro\} berasal dari kata hydro bahasa Inggris yang berarti air.Sedangkan morfem \{ grafis\} berasal dari kata graf yang bermakna tulisan. Sehingga yang dimaksud hidrografis dalam kajian ini yaitu leksikon air atau mizu dalam peribahasa bahasa Jepang dan cai (ci) dalam bahasa Sunda. Sebagai contoh dalam peribahasa Jepang terdapat peribahasa yang berbunyi mizu to abura'air dan minyak,. Peribahasa ini dalam bahasa Sunda sepadan dengan kawas cai jeung minyak 'seperti air dan minyak' . Berdasarkan sifat kedua benda cair tersebut yang tidak dapat bercampur karena perbedaan massa yaitu berat jenis minyak lebih ringan daripada air. Makah hal ini menjadi konvensi yang universal. Oleh karena itu, kedua peribahasa 
ini memiliki makna yang sama yaitu tidak dapat disatukan atau tidak ada keharmonisan. Contoh di atas, merupakan salah satu contoh kesepadanan bentuk dan makna dari kedua peribahasa tersebut. Di pihak lain terdapat peribahasa mizu tsumorite sakana atsumaru' Kalau air banyak, maka ikan pun akan datang berkumpul'. Peribahasa ini dalam bahasa Sunda sepadan dengan aya gula aya sireum ' ada gula ada semut' atau aya kembang, kukupu datang ' ada bunga yang sedang mekar, maka kupu-kupu pun akan datang. Kedua peribahasa tersebut dari segi makna sama yaitu bila ada sesuatu yang disenangi atau dimana ada gadis, maka pemuda akan datang menghampirinya. Namun, dari segi rujukan benda berbeda. Perbedaan dan persamaan di atas, dapat disebabkan karena adanya pandangan hidup yang berbeda antara masyarakat Jepang dan Masyarakat Indonesia. Hal ini menjadi permasalahan terutama bagi pembelajar bahasa Jepang yang berbahasa ibu bahasa Indonesia. Selain itu, sampai saat ini belum ada penelitian peribahasa Jepang dan Sunda yang terkait dengan air. Oleh karena itu, penelitian ini bertujuan untuk mendeskripsikan makna budaya mizu 'air' dalam peribahasa Jepang dan padanannya dalam peribahasa bahasa Sunda.

\section{B. Metode}

Metode yang digunakan dalam penelitian ini adalah metode deskriptif kualitatif dengan pendekatan etnolinguistik.. Etnolinguistik dapat didefinisikan sebagai cabang linguistik yang dapat digunakan untuk mempelajari struktur bahasa dan atau kosakata bahasa masyarakat etnis tertentu berdasarkan cara pandang dan budaya yang dimiliki masyarakat penuturnya dalam rangka menyibak atau mengungkap budaya masyarakat tersebut (Baehaqi, 2013: 15). Data yang digunakan berupa peribahasa Jepang yang mengandung leksikon mizu dan ame. Leksikon yang digunakan dalam kajian ini merupakan kata-kata yang terkait dengan air. 
Sesuai dengan pendapat Rahyono (2015: 103) disebutkan bahwa terdapat kearifan budaya dalam kata. Jadi, kata-kata dalam bahasa Jepang yang terkait dengan air mengandung budaya dan bagaimana orang Jepang memandangnya secara budaya. Data terkumpul 11 peribahasa dengan komposisi tujuh peribahasa yang mengandung kata mizu 'air' dan empat yang mengandung kata ame 'hujan'. Kata ame digunakan karena masih terkait dengan air. Setelah data terkumpul kemudian diklasifikasikan berdasarkan struktur. Hasil klasifikasi teridentifikasi peribahasa yang berstruktur berpasangan (tiga buah), kontradiktif (dua buah), bersajak (empat buah), dan perbandingan (dua buah). Dari hasil klasifikasi struktur selanjutnya dianalisis berdasarkan makna dari unsur-unsur pembentuk kalimat yang berupa peribahasa tersebut. Setelah itu, dideskripsikan makna harafiahnya. Setelah makna harafiah teridentifikasi kemudian dipadankan dengan peribahasa dalam bahasa Sunda. Pemadaman makna disesuaikan dengan pandangan masyarakat Sunda dan Jepang terhadap leksikon air dan bandingannya atau padanannya dengan leksikon dalam peribahasa Sunda. Setelah itu,ditemukan makna budaya dari setiap data, dan terakhir ditarik simpulan.

\section{Hasil dan Pembahasan}

Pada bagian ini dideskripsikan peribahasa Jepang yang terkait dengan air dan padanannya dalam peribahasa Sunda.

\section{Peribahasa Berstuktur Berpasangan.}

(1)水心あれば魚心あり

\section{Mizugokoro areba uogokoro ari}

Peribahasa di atas secara struktur terdiri atas dua klausa yaitu mizugokoro areba dan uogokoro ari. Secara kategori klausa pertama yang bersubjek mizugoro dan subjek klausa kedua yang diisi oleh 
uogokoro. Masing-masing subjek berupa nomina majemuk yang terdiri atas dua morfem yaitu morfem $\{\mathrm{mizu}\}$ dan $\{\mathrm{g}(\mathrm{k})$ okoro $\}$ serta $\{\mathrm{uo}\}$ dan $\{\mathrm{g}(\mathrm{k})$ okoro\}. Kedua klausa tersebut beruba verba keberadaan. Secara stuktur kedua nomina majemuk tersebut berstuktur sintaktis. Baik mizu maupun uo sebagai inti dan $\{\mathrm{g}(\mathrm{k})$ okoro $\}$ sebagai atribut. Oleh karena itu, secara harfiah klausa yang pertama bermakna kalau ada air dan klausa yang kedua bermakna ada ikan.

Dalam peribahasa tersebut, kata mizu 'air' disejajarkan dengan kata 'ikan'. Hal ini dikarena ikan hidup di air. Sedangkan kata gokoro yang berasal dari kata kokoro yang memiliki makna denotatif hati, namun dalam peribahasa ini bermakna habitat. Jadi habitat ikan adalah air. Sehingga jika ada air, di situ akan ada ikan. Dari segi struktur peribahasa di atas termasuk peribahasa berpasangan.Peribahasa di atas, dalam bahasa Sunda sepadan dengan peribahasa yang berbunyi batu turun keusik naek 'batu turun pasir naik' (Rosidi, 2005: 32). Berdasarkan peribahasa di atas, benda yang disebut batu 'batu' dalam bahasa Sunda tidak jauh dari benda sejenisnya yaitu keusik 'pasir'. Kedua benda tersebut berupa benda padat, namun yang membedakannya adalah walaupun terdapat batu kecil namun dalam peribahasa ini batu yang dimaksud adalah batu besar. Dan kata turun 'turun' berantonim dengan naek 'naik'. Bila yang satu naik dan yang satu turun . Maka akan bertemu di tengah-tengah. Keberadaan dan pertemuan dari kedua benda dari kedua peribahasa tersebut bermakna adanya kecocokan. Sehingga peribahasa di atas bermakna jika seseorang memiliki suatu niatan terhadap pihak lain, maka pihak lain pun akan memiliki keinginan untuk memberikan respon. Dalam budaya Jepang air dipasangkan dengan ikan sebagai tempat habitat. Keberadaan pasangan ini menunjukkan kecocokan antara keduanya. Namun, dalam budaya Sunda kecocokan ditandai dengan adanya gerakan yaitu bila yang satu turun dan lawannya naik, sehingga bertemu di tengah-tengah. Dengan demikian kecocokan dalam 
budaya Jepang ditandai oleh benda yang berada sebagai habitatnya. Sedangkan dalam bahasa Indonesia kecocokan digambarkan dengan adanya kegiatan yang dapat mempertemukan ditengah-tengah agar dapat saling meringankan. Kesejajaran dan perbedaan masing-masing kedua benda tersebut dapat digambarkan seperti berikut.

Tabel 1: Perbandingan Peribahasa Berpasangan.

\begin{tabular}{|c|c|c|c|c|}
\hline \multirow[t]{2}{*}{$\begin{array}{l}\text { Peribahasa } \\
\text { Jepang }\end{array}$} & \multirow[t]{2}{*}{$\begin{array}{l}\text { Peribahasa } \\
\text { Sunda }\end{array}$} & \multicolumn{2}{|c|}{$\begin{array}{l}\text { Perbedaan/Persamaan } \\
\text { ditunjukkan dengan }\end{array}$} & \multirow[t]{2}{*}{$\begin{array}{l}\text { Makna } \\
\text { Peribahasa }\end{array}$} \\
\hline & & Jepang & Sunda & \\
\hline $\begin{array}{l}\text { Mizugokoro } \\
\text { uogokoro }\end{array}$ & $\begin{array}{l}\text { Batu turun } \\
\text { keusik naek } \\
\text { 'Batu turun } \\
\text { pasir naik' }\end{array}$ & $\begin{array}{l}\text { verba } \\
\text { keberadaan }\end{array}$ & Verba kegiatan & $\begin{array}{l}\text { Ada } \\
\text { kecocokan }\end{array}$ \\
\hline
\end{tabular}

(2) 水魚の交わり

\section{Suigyo no majiwari}

Peribahasa di atas berupa klausa nomina yang bersubjek suigyou 'air dan ikan' dan berpredikat majiwari 'percampuran'. Jadi secara makna klausa tersebut bermakna percampuran antara air dan ikan. Air merupakan habitat ikan. Jadi ikan sangat bergantung pada keberadaan air. Atau dengan kata lain, kehidupan ikan tidak dapat dipisahkan dari air. Ketergantungan ikan terhadap air tersebut dalam peribahasa Sunda sepadan dengan peribahasa yang berbunyi gula jeung peueut 'gula dan peueut'. Peueut adalah air nira yang dididihkan sebelum menjadi gula'. Baik gula maupun peueut sama memiliki rasa manis. Sifat manis kedua benda tersebut diibaratkan hubungan manusia yang sangat harmonis. Begitu pula percampuran antara air dan ikan. Kecocokan atau keharmonisan antara dua makhluk atau benda tersebut digambarkan menjadi peribahasa di atas yang bermakna hubungan persahabatan atau pertemanan yang sangat erat seperti menyatunya air dengan ikan atau gula dan peueut. Jadi makna mizu dari peribahasa (3) bermakna persahabatan yang memiliki hubungan yang harmonis. 
Tabel 2: Perbandingan Peribahasa Berpasangan

\begin{tabular}{|l|l|l|l|l|}
\hline Peribahasa & $\begin{array}{l}\text { Peribahasa } \\
\text { Sunda }\end{array}$ & \multicolumn{2}{|l|}{$\begin{array}{l}\text { Pe r b e d a n / Pe r s m a a n } \\
\text { ditunjukkan dengan }\end{array}$} & Makna Peribahasa \\
\cline { 3 - 4 } & Jepang & Sunda & \\
\hline $\begin{array}{l}\text { Suigyo no } \\
\text { majiwari }\end{array}$ & $\begin{array}{l}\text { gula jeung } \\
\text { peueut } \\
\text { gula dan } \\
\text { peueut' }\end{array}$ & kesejajaran & Penambahan & $\begin{array}{l}\text { Hubungan dua insan } \\
\text { yang sangat harmonis }\end{array}$ \\
\hline
\end{tabular}

\section{(3)雨の降る日は天気が悪い}

\section{Ame no furu hi wa tenki ga warui}

Peribahasa di atas merupakan kalimat ajektifal. Subjek dari kalimat tersebut adalah ame no furu hi' hari hujan' dan predikatnya adalah warui 'jelek', sedangkan tenki 'cuaca' berkedudukan sebagai topik. Antara subjek, predikat, dan topik merupakan suatu kewajaran yang dianggap sebagai konvensi yang universal. Jadi secara harafiah peribahasa tersebut bermakna pada hari hujan, cuaca buruk. Sebaliknya ketika tidak hujan, cuaca akan bagus. Peribahasa di atas, dalam peribahasa Sunda sepadan dengan peribahasa yang berbunyi Geus ti Kudratna. Adat ka kurung ku iga. Makna peribahasa tersebut yaitu sesuatu yang memang sudah selayaknya begitu. Ungkapan ironis terhadap sesuatu yang sudah selayaknya seperti itu namun diungkapkan dengan penuh keseriusan seolah hal tersebut adalah kebenaran. Mengapa demikian, sebenarnya ketika hujan turun belum tentu cuaca jelek, dan walaupun air dari hulu tidak begitu bagus, air yang mengalir ke hilir belum tentu jelek. Karena hal itu dapat diperbaiki. Namun, pandangan masyarakat sudah umumnya seperti itu. Dalam budaya Sunda kena dengan peribahasa yang berbunyi Geus ti Kudratna. Adat ka kurung ku iga. 
Tabel 3: Perbandingan Peribahasa Berpasangan

\begin{tabular}{|l|l|l|l|l|}
\hline \multirow{2}{*}{$\begin{array}{l}\text { Peribahasa } \\
\text { Jepang }\end{array}$} & \multirow{2}{*}{$\begin{array}{l}\text { Peribahasa } \\
\text { Sunda }\end{array}$} & $\begin{array}{l}\text { Perbedaan/Persamaan } \\
\text { merujuk pada }\end{array}$ & $\begin{array}{l}\text { Makna } \\
\text { Peribahasa }\end{array}$ \\
\cline { 3 - 4 } & Jepang & Sunda & \\
\hline $\begin{array}{l}\text { Ame no furu } \\
\text { hi wa tenki ga } \\
\text { warui }\end{array}$ & $\begin{array}{l}\text { Geus ti } \\
\text { Kudratna. } \\
\text { Adat ka } \\
\text { kurung ku } \\
\text { iga. }\end{array}$ & $\begin{array}{l}\text { Pasangan } \\
\text { hujan dan } \\
\text { cuaca buruk. }\end{array}$ & sifat & $\begin{array}{l}\text { Sesuatu yang } \\
\text { memang sudah } \\
\text { selayaknya } \\
\text { begitu. }\end{array}$ \\
\hline
\end{tabular}

\section{Peribahasa Berstuktur Kontradiktif.}

(1)水と油

\section{Mizu to abura}

Peribahasa di atas terdiri atas tiga kata yaitu kata mizu 'air' , abura 'minyak', dan partikel to' dan' yang bersifat penambahan. Air memiliki massa atau berat. Massa air lebih berat daripada minyak. Sehingga bila air dicampukan dengan minyak, maka minyak akan berada di atas permukaan air yang mengakibatkan minyak tidak akan bercampur atau larut dalam air. Keuniversalan kedua sifat benda cair tersebut menjadi konvensi di kedua masyarakat budaya Jepang dan Sunda. Masyarakat Jepang merupakan masyarakat yang menganut konsep "kelompok" ( shuudan shugi). Begitu pula, orang Sunda sebagai masyarakat yang menganut hidup berkumpul dengan keluarga atau saudaranya atau dalam peribahasa Sunda disebut masyarakat yang menganut bengkung ngariung bongkok ngaronyok 'selalu bersama. Namun secara pribadi mereka tetap sebagai individu yang memiliki sifat masing-masing yang memungkinkan muncul keegoan sehingga tidak cocok antara satu dengan lainnya. Ketidak cocokkan tersebut diibaratkan seperti dua benda cair yaitu air dan minyak yang bila dicampurkan pun tetap tidak bisa bersatu. Sehingga, diantara kedua sifat benda tersebut menjadi peribahasa dalam bahasa Jepang dan 
bahasa Sunda. Namun, dalam dalam bahasa Sunda itu menjadi ibarat sehingga ditambah dengan kata jiga 'seperti' yaitu "kawas cai jeung minyak 'seperti air dan minyak'. Peribahasa ini mengibaratkan atau penggambaran dua manusia atau dua kelompok manusia yang sama sekali tidak memiliki kecocokan atau tidak ada keharmonisan.

Tabel 4: Perbandingan Peribahasa Berstruktur Kontradiktif

\begin{tabular}{|l|l|l|l|}
\hline Peribahasa Jepang & Peribahasa Sunda & Persamaan & Makna Peribahasa \\
\cline { 3 - 3 } & & Jepang - Sunda & \\
\hline mizu to abura & cai jeung minyak & $\begin{array}{l}\text { Konjungsi } \\
\text { yang bersifat } \\
\text { 'air dan minyak' }\end{array}$ & 'air dan minyak ada kecocokan \\
penambahan? & & \\
\hline
\end{tabular}

(2)水は船を乗せ、また、船を覆す。

\section{Mizu wa funa o nose mata fune o kutsugaesu}

Peribahasa ini terdiri atas dua klausa yang masing-masing klausa berpredikat verba terhadap objek fune (a) 'perahu'. Sedangkan mizu' sebagai' subjeknya. Predikat dari klausa pertama yaitu verba nose ' menaikkan' dan predikat dari klausa kedua yaitu kutsugaesu ' menggulingkan' atau 'menumbangkankan' atau 'membalikkan' . Jadi, peribahasa ini merupakan peribahasa yang berstuktur kontradiktif. Dalam satu fihak air dapat menguntungkan yang diwujudkan dengan klausa pertma dan yang kedua bersifat merugikan atau membahayakan. Peribahasa ini, dalam bahasa Sunda sepadan dengan peribahasa yang berbunyi jiga cai, jiga seuneu 'seperti air, seperti api'. Air dan api bila sedikit atau kuantitasnya sesuai dengan keperluan kehidupan manusia sangat bermanfaat, misalnya air untuk mandi, cuci, dll. Begitu pula api kalau kecil bermanfaat sebagai penerangan dan dapat digunakan untuk memasak. Namun, sebaliknya kalau kedua zat ini terlalu besar dapat menyebabkan nkerugian bagi manusia seperti dapat mendatangkan banjir atau kebakaran.

Dari segi budaya baik dalam budaya Jepang maupun budaya Sunda leksikon air dari zat cair ini menjadi symbol dalam kehidupan manusia. Namun, perlu diwaspadai karena dapat dimanfaatkan, tetapi sebaliknya dapat mengakibatkan kerugian. Perbedaannya dalam 
masyarakat Jepang yang dekat dengan alam (laut) kata air didekatkan dengan alat transfortasi yang ada di air. Namun, dalam budaya Sunda, kata air disejajarkan dengan api yang mana dapat memberikan manfaat apabila dijadikan pemenuhan kebutuhan hidup. Sebaliknya dapat menimbulkan mala petaka apabila keberadaannya di luar batas. Oleh karena itu, nasihat yang terkandung di dalam peribahasa ini adalah himbauan untuk berhati-hati dalam menghadapai kedua zat ini.

Tabel 5: Perbandingan Peribahasa Berstruktur Kontradiktif

\begin{tabular}{|c|c|c|c|c|}
\hline \multirow{2}{*}{$\begin{array}{l}\text { Peribahasa } \\
\text { Jepang }\end{array}$} & \multirow{2}{*}{$\begin{array}{l}\text { Peribahasa } \\
\text { Sunda }\end{array}$} & \multicolumn{2}{|c|}{ Perbedaan/Persamaan merujuk pada } & \multirow{2}{*}{$\begin{array}{l}\text { Makna } \\
\text { Peribahasa }\end{array}$} \\
\hline & & Jepang & Sunda & \\
\hline $\begin{array}{l}\text { Mizu wa } \\
\text { funa o } \\
\text { nose mata } \\
\text { fune o } \\
\text { kutsugaesu }\end{array}$ & $\begin{array}{l}\text { jiga cai, } \\
\text { jiga seuneu } \\
\text { 'seperti air, } \\
\text { seperti api' }\end{array}$ & $\begin{array}{l}\text { Kontradiksi } \\
\text { menguntungkan } \\
\text { dan merugikan }\end{array}$ & $\begin{array}{l}\text { Kontradiksi sifat } \\
\text { besar (merugikan) } \\
\text { dan kecil } \\
\text { (menguntungkan). }\end{array}$ & $\begin{array}{l}\text { Nasihat } \\
\text { untuk } \\
\text { berhati-hati. }\end{array}$ \\
\hline
\end{tabular}

\section{Peribahasa Berstuktur Sajak.}

Dalam Kamus Besar Bahasa Indonesia ( KBBI) disebutkan bahwa sajak adalah persamaan bunyi; rima dalam pantun, syair, dan sebagainya terutama pada akhir baris ( KBBI, 1995: 862). Berdasarkan definisi di atas peribahasa berstuktur sajak dalam bahasa Jepang selain ditentukan oleh bunyi akhir ditentukan pula oleh jumlah silabel atau suku kata dalam setiap frasa seperti yang terdapat dalam peribahasa berikut.

\section{(1).水は方円の器に随う}

\section{Mizu wa houen no utsuwa ni shitagau}

Peribahasa di atas merupakan kalimat verbal dengan subjek mizu 'air' dan predikat shitagau' mengikuti', serta keterangan houen no utsuwa 'bentuk wadah'. Sehingga secara harafiah peribahasa tersebut bermakna air mengikuti bentuk wadah ( di mana air itu berada). Air bersifat menempati ruang dan berubah wujud sesuai benda 
atau tempat air berada. Air merupakan benda yang sangat fleksibel. Artinya, air dapat dengan mudah berubah bentuk sesuai dengan wadah yang menampungnya. Sifat ini merupakan sifat yang unik yang dimiliki oleh air dan bahkan tidak dimiliki oleh benda padat. Air akan mengikuti bentuk wadah yang menampungnya. Peribahasa di atas merupakan nasihat yang berupa himbauan. Faktor lingkungan sangat besar pengaruhnya terhadap kepribadian seseorang. Dalam budaya Sunda terdapat ungkapan atau peribahasa yang berbunyi lamun deudeukeutan reujeung tukang kembang, pasti kaantelan seungitna kembang, tapi lamun reureujeungan jeung tukang tarasi pasti kaeunteupan bauna tarasi ' kalau berteman dengan penjual bunga akan terkena harumnya bunga, sebaliknya kalau berteman dengan penjual terasi akan terkena baunya terasi'. Jadi, himbauan ini dalam konsep masyarakat Sunda sama dengan konsep pengkuh agamana ' kuat agamanya' atau kuat imannya.

Tabel 6: Perbandingan Peribahasa Bersajak

\begin{tabular}{|l|l|l|l|l|}
\hline \multirow{2}{*}{$\begin{array}{l}\text { Peribahasa } \\
\text { Jepang }\end{array}$} & Peribahasa Sunda & \multicolumn{2}{|l|}{$\begin{array}{l}\text { Perbedaan/Persamaan } \\
\text { merujuk pada }\end{array}$} & $\begin{array}{l}\text { Makna } \\
\text { Peribahasa }\end{array}$ \\
\cline { 2 - 4 } $\begin{array}{l}\text { Mizu wa houen } \\
\text { no utsuwa ni } \\
\text { shitagau }\end{array}$ & $\begin{array}{l}\text { Jepang } \\
\text { lamun } \\
\text { deudeukeutan } \\
\text { reujeung tukang } \\
\text { kembang, pasti } \\
\text { kaantelan seungitna } \\
\text { kembang, tapi lamun } \\
\text { reureujeungan jeung } \\
\text { tukang tarasi } \\
\text { pasti kaeunteupan } \\
\text { bauna tarasi' } \\
\text { kalau berteman } \\
\text { dengan penjual } \\
\text { bunga akan terkena } \\
\text { harumnya bunga, } \\
\text { sebaliknya kalau } \\
\text { berteman dengan } \\
\text { penjual terasi akan } \\
\text { terkena baunya } \\
\text { terasi'. }\end{array}$ & tempat & relasi & $\begin{array}{l}\text { Sunda } \\
\text { buruk sesuai } \\
\text { dengan } \\
\text { lingkungan } \\
\text { atau orang- } \\
\text { orang yang } \\
\text { menjadi } \\
\text { temannya }\end{array}$ \\
\hline
\end{tabular}


(2) 雨垂れ石を穿つ

Amadare ishi o ugatsu

Peribahasa di atas berupa kalimat verbal dengan predikat amadare ' tetesan air', predikat ugatsu 'cocok' atau 'persis', dan objek diisi oleh ishi'batu'. Sehingga peribahasa tersebut secara harafiah bermakna denotative tetesaan air jatuh persis ke batu. Sudah disebutkan di atas, bahwa air memiliki berat. Selain itu air dapat meresap melalui celah kecil. Sedangkan batu walaupun termasuk benda padat, namun tetap memiliki pori-pori yang dapat air meresap ke dalamnya. Setelah air meresap seiring dengan kapilaritas sifat air atau air dapat bergerak menuju ke atas melawan gaya gravitasi bumi. Maka air dapat membasahi keseluruhan batu dan lama-kelamaan batu akan berubah apakah menjadi pecah atau berubah menjadi berlubang sesuai cucuran airnya. Dalam peribahasa ini, air sebagai benda cair dibandingkan dengan batu yang bersifat padat sehingga bersifat antonym. Namun, sekecil apapun air tetap memiliki massa. Dan massa dari titik-titik air tersebut apabila dilakukan secara terus menerus jatuh pada tempat yang sama, akan membuat bagian tempat tersebut berlubang, meski itu berupa batu sekali pun. Peribahasa ini dalam bahasa Sunda sepadan dengan peribahasa yang berbunyi Cikaracak ninggang batu laun-laun jadi legok. Bahkan dalam bahasa Inggris pun terdapat peribahasa yang bermakna sama yaitu Constant dripping wears away the stone. Keuniversalan ini menjadi konvensi baik dalam bahasa Jepang maupun dalam peribahasa Sunda. Sehingga peribahasa tersebut bermakna jika kita berusaha dengan ulet tanpa henti, suatu saat apa yang kita harapkan akan terkabul (berhasil). Peribahasa di atas dari segi struktur termasuk pada peribahasa bersajak. 
Tabel 7: Perbandingan Peribahasa Bersajak

\begin{tabular}{|l|l|l|l|l|}
\hline \multirow{2}{*}{$\begin{array}{l}\text { Peribahasa } \\
\text { Jepang }\end{array}$} & $\begin{array}{l}\text { Peribahasa } \\
\text { Sunda }\end{array}$ & \multicolumn{2}{|l|}{ Perbedaan/Persamaan } & Makna \\
\cline { 3 - 5 } & Jepang & Sunda & \\
\hline $\begin{array}{l}\text { Amadare ishi } \\
\text { o ugatsu }\end{array}$ & $\begin{array}{l}\text { Cikaracak } \\
\text { ninggang batu } \\
\text { laun-laun jadi } \\
\text { legok }\end{array}$ & jatuh & $\begin{array}{l}\text { Ninggang } \\
\text { jatuh mengenai } \\
\text { sesuatu' }\end{array}$ & $\begin{array}{l}\text { Kesabaran/ } \\
\text { kebertahanan }\end{array}$ \\
\hline
\end{tabular}

\section{(3).水に慣れる}

\section{Mizu ni nareru}

Peribahasa di atas berpredikat nareru 'terbiasa' dan keterangan yaitu mizu 'air'. Secara harafiah peribahasa tersebut bermakna terbiasa dengan air. Dalam QS Al-Mu'minun : 18 dijelaskan bahwa Kami turunkan air dari langit menurut suatu ukuran. Lalu, Kami jadikan air itu menetap di bumi....... . Berdasarkan ayat di atas, manusia makan, minum, dan hidup dari sumber air di bumi yang ada di sekitar mereka tinggal. Karakteristik air suatu tempat akan ditentukan oleh karakteristik bumi yang mengandungnya. Manusia sebagai pengguna air tersebut lama-kelamaan akan terbiasa dan dapat merasakan sifat dan rasa air setempat. Sehingga air tersebut akan membentuk sifat dan karakter peminumnya. Hal ini berlaku secara universal khususnya baik di Jepang maupun di wilayah masyarakat Sunda tinggal. Oleh karena itu, di masyarakat Sunda, seseorang atau sekelompok manusia yang sangat dekat dan mampu merasakan kehidupan dan budaya setempat sampai tidak bisa dipisahkan antara satu dengan yang lainnya. Dan sering mendapat julukan geus kainum caina 'sudah terminum airnya'. Zat-zat yang terkandung dalam air tersebut sudah membentuk rasa, karsa, dan karya masyarakat peminum atau penggunanya. Sehingga makna dari peribahasa tersebut adalah seseorang sudah terbiasa dengan lingkungan di mana mereka tinggal. 
Tabel 8: Perbandingan Peribahasa Bersajak

\begin{tabular}{|l|l|l|l|l|}
\hline \multirow{2}{*}{$\begin{array}{l}\text { Jepibahasa } \\
\text { Sunda }\end{array}$} & $\begin{array}{l}\text { Peribahasa } \\
\text { Sund }\end{array}$ & $\begin{array}{l}\text { Perbedaan/Persamaan } \\
\text { merujuk pada }\end{array}$ & Makna Peribahasa \\
\cline { 2 - 4 } & Jepang & Sunda & \\
\hline Mizu nareru & $\begin{array}{l}\text { Geus } \\
\text { kainum } \\
\text { caina } \\
\text { 'sudah } \\
\text { terminum } \\
\text { airnya' }\end{array}$ & Verba nareru & $\begin{array}{l}\text { Verba } \\
\text { Kainum } \\
\text { terminum' }\end{array}$ & Sudah terbiasa \\
\hline
\end{tabular}

(4) 雨晴れて笠を忘る

\section{Ame harete kasa o wasuru}

Peribahasa no (4) terdiri atas dua klausa, klausa pertama yaitu ame harete 'cuaca baik' dan klausa kedua kasa o wasuru 'membawa payung'. Morfem \{-te\} pada kata wasurete merupakan partikel penghubung yang menyatakan penghubung dari kegiatan yang dinyatakan klausa pertama dengan klausa kedua. Secara harafiah peribahasa tersebut bermakna hujan reda, lupa caping.Peribahasa di atas dalam bahasa Sunda sepadan dengan peribahasa yang berbunyi nulungan anjing kacepet, poho kana purwadaksina 'menolong anjing kejepit, lupa pada asal mula'. Peribahasa tersebut bermakna Jika sudah dapat melewati suatu kesulitan, biasanya lupa akan budi atau jasa orang yang telah menolongnya.

Perbandingan peribahasa tersebut dapat dilihat dalam table berikut.

Tabel 9: Perbandingan Peribahasa Bersajak

\begin{tabular}{|c|c|c|c|c|}
\hline \multirow[t]{2}{*}{$\begin{array}{l}\text { Peribahasa } \\
\text { Jepang }\end{array}$} & \multirow[t]{2}{*}{$\begin{array}{l}\text { Peribahasa } \\
\text { Sunda }\end{array}$} & \multicolumn{2}{|c|}{$\begin{array}{l}\text { Perbedaan/Persamaan } \\
\text { merujuk pada }\end{array}$} & \multirow[t]{2}{*}{ Makna Peribahasa } \\
\hline & & Jepang & Sunda & \\
\hline $\begin{array}{l}\text { Ame harete } \\
\text { kasa o } \\
\text { wasuru }\end{array}$ & $\begin{array}{l}\text { Nulungan } \\
\text { anjing kajepet, } \\
\text { poho kana } \\
\text { purwadaksina }\end{array}$ & cuaca & prilaku & $\begin{array}{l}\text { sudah dapat } \\
\text { melewati suatu } \\
\text { kesulitan, biasanya } \\
\text { lupa akan budi atau } \\
\text { jasa orang yang telah } \\
\text { menolongnya. }\end{array}$ \\
\hline
\end{tabular}




\section{Peribahasa Berstuktur Perbandingan}

\section{(1)雨に髪洗い風に櫛げずる}

\section{Ame ni kamiarai kaze ni kushikezuru}

Peribahasa di atas terdiri atas dua kalimat, yaitu ame ni kamiarai 'dikeramas dengan air hujan dan kaze ni kushikezuru 'disisir dengan angin'. Secara harafiah bermakna dikeramasi dengan air hujan, disisir dengan angin. Air hujan secara alami bersifat asam dengan $\mathrm{pH}$ sedikit di bawah 6. Hal ini terjadi karena karbondioksida $\left(\mathrm{CO}_{2}\right)$ di udara yang larut dengan air hujan memiliki bentuk sebagai asam lemah. Jenis asam dalam hujan ini sangat bermanfaat karena membantu melarutkan mineral dalam tanah yang dibutuhkan oleh tumbuhan dan binatang. Namun, menurut pandangan masyarakat Jepang, air hujan bila digunakan untuk mencuci rambut kurang bagus. Dalam peribahasa di atas, kata ame'hujan' disejajarkan dengan kata kaze 'angin'. Kedua kata ini bila sesuai dengan yang dibutuhkan akan menyegarkan bagi manusia, namun ketika hujan deras dan angin kencang datang bersamaan akan menyebabkan kerugian bagi manusia. Rambut manusia perlu dicuci atau dikeramas serta perlu pula dirapikan atau disisir. Namun, bila dicuci dengan air hujan dan disisir dan tiupan angin, tidak akan menghasilkan rambut yang rapih dan bersih, malah sebaliknya dan tidak bagi pemilik rambut tersebut maupun orang lain yang melihatnya. Peribahasa di atas sepadan dengan peribahasa Sunda yang berbunyi cai asak tuak bari, kejo asa catang bobo ( Tamsyah, 2001:249). Peribahasa tersebut bila diterjemahkan ke dalam bahasa Indonesia yaitu 'air serasa tuak basi, dan nasi serasa kayu lapuk'. Dua hal ini baik dalam peribahasa Jepang maupun dalam peribahasa Sunda menggambarkan kesulitan. Sehingga makna dari kedua peribahasa ini adalah menjalani kehidupan yang sangat susah atau mengalami berbagai macam kesulitan dalam mengarungi kehidupan di masyarakat. 
Tabel 10: Perbandingan Peribahasa Perbandingan

\begin{tabular}{|l|l|l|l|l|}
\hline \multirow{2}{*}{$\begin{array}{l}\text { Peribahasa } \\
\text { Jepang }\end{array}$} & Peribahasa Sunda & \multicolumn{2}{|l|}{$\begin{array}{l}\text { Perbedaan/Persamaan } \\
\text { Merujuk pada... }\end{array}$} & $\begin{array}{l}\text { Makna } \\
\text { Peribahasa }\end{array}$ \\
\cline { 3 - 4 } & & Jepang & Sunda & \\
\hline $\begin{array}{l}\text { Ame ni kamiarai } \\
\text { kaze ni }\end{array}$ & $\begin{array}{l}\text { cai asak tuak bari, } \\
\text { kejo asa catang } \\
\text { kobo 'air serasa } \\
\text { kuak basi, dan nasi } \\
\text { serasa kayu lapuk' }\end{array}$ & $\begin{array}{l}\text { Dikeramas } \\
\text { dan disisir } \\
\text { oleh sesuatu } \\
\text { yang bukan } \\
\text { alatnya. }\end{array}$ & $\begin{array}{l}\text { Rasa } \\
\text { yang } \\
\text { tidak } \\
\text { enak. }\end{array}$ & $\begin{array}{l}\text { menjalani } \\
\text { kehidupan yang } \\
\text { sangat susah }\end{array}$ \\
\hline
\end{tabular}

(2).水清ければ月宿る

\section{Mizu kiyokereba tsuki yadoru}

Peribahasa di atas terdiri atas dua klausa yaitu mizu kiyokereba kalau air bersih' dan tsuki yadoru 'bulan berlindung'. Sehingga secara harafiah peribahasa tersebut adalah kalau air jernih, bulan pun akan muncul. Di air bersih, bila bulan sedang muncul baik bulan sabit maupun bulan purnama akan tampak pantulan atau bayangannya. Dalam peribahasa di atas, air bersih disejajarkan dengan rembulan. Air sebagai sumber kehidupan manusia di bumi, begitu pula bulan dapat menerangi seluruh alam. Sehingga air dan bulan dianggap sebagai benda yang sangat sakral dan istimewa. Air jernih dalam peribahasa Jepang di atas, dalam peribahasa Sunda sepadan dengan peribahasa yang berbunyi clik putih clak bodas, cai nyacas bisa dipake ngeunteung (Nugraha, 2014: 19). Peribahasa tersebut dalam bahasa Indonesia dapat diterjemahkan menjadi 'air jernih dapat dijadikan cermin'. Clik merupakan onomatope untuk air yang menetes berukuran kecil dan clak untuk berukuran agak besar di atas clik. Air jernih dalam kedua peribahasa tersebut menggambarkan kebersihan jiwa atau hati seseorang. Orang yang berhati bersih pasti berprilaku baik, sehingga dapat dijadikan cermin atau contoh bagi orang lain. Perbandingan kedua peribahasa di atas dapat dilihat dalam table berikut. 
Tabel 11: Perbandingan Peribahasa Berstruktur Perbandingan

\begin{tabular}{|c|c|c|c|c|}
\hline \multirow[t]{2}{*}{$\begin{array}{l}\text { Peribahasa } \\
\text { Jepang }\end{array}$} & \multirow[t]{2}{*}{$\begin{array}{l}\text { Peribahasa } \\
\text { Sunda }\end{array}$} & \multicolumn{2}{|c|}{$\begin{array}{l}\text { Perbedaan/Persamaan } \\
\text { merujuk pada }\end{array}$} & \multirow[t]{2}{*}{$\begin{array}{l}\text { Makna } \\
\text { Peribahasa }\end{array}$} \\
\hline & & Jepang & Sunda & \\
\hline $\begin{array}{l}\text { Mizu } \\
\text { kiyokereba } \\
\text { tsuki } \\
\text { yadoru }\end{array}$ & $\begin{array}{l}\text { Clik putih Clak } \\
\text { bodas, cai } \\
\text { nyacas }\end{array}$ & Air-bulan & $\begin{array}{l}\text { Warna yang } \\
\text { bersih (nyacas) } \\
\text { 'putih bersih } \\
\text { sampai dapat } \\
\text { digunakan untuk } \\
\text { bercermin' }\end{array}$ & $\begin{array}{l}\text { Hati yang } \\
\text { bersih akan } \\
\text { mengundang } \\
\text { berkah }\end{array}$ \\
\hline
\end{tabular}

\section{D.Simpulan}

Berdasarkan analisis di atas, teridentifikasi bahwa kata air dan mizu baik dalam masyarakat Jepang maupun masyarakat Sunda menjadi simbol betapa pentingnya keberadaan zat ini sebagai sumber penghidupan sehingga muncul menjadi bagian dalam peribahasa. Berdasarkan data, baik dalam budaya Jepang maupun dalam budaya Sunda air dapat dijadikan symbol penentu sifat dan karakter. Sebaliknya terdapat perbedaan dalam peribahasa Jepang air atau zat yang mengandung air seperti hujan tidak selalu sepadan dengan munculnya leksikon air, namun digunakan leksikon dari zat lain seperi batu dan keusik 'pasir'. Selain itu, antonim verba dalam peribahasa Jepang muncul sebagai aksi atau sifat dari subjek (mizu). Sebaliknya dalam budaya Sunda dipadankan dengan benda alam lainnya yang memiliki kesamaan fungsi dalam kehidupan manusia.

\section{DAFTAR PUSTAKA}

Al-Qur-an Tajwid Warna Al-Mu'asir Cetakan III. Muharram 1438/ Oktober 2016.Bandung: CV. Khazanah Intelektual. Baehaqi, Imam. 2013. Etnolinguistik Telaah Teoritis Dan Praktis. Surakarta: Cakrawala Media. 
Fujii, Otoo. 2007. Kotowaza no Kenkyuu,2007. Tokyo: Koudansha.

Nugraha, D. 2008. Ngamumule Basa Sunda 1200 Paribasa. Bandung: Yrama Widya.

Rahyono,F.,X.2015. Kearifan Budaya dalam Kata. Jakarta: Wedatama Widya Sastra.

Rosidi, Ayip. 2005. Babasan \& Paribasa.Bandung: Kiblat.

Tamsyah, R., Budi.2002. Galuring Basa Sunda. Bandung: Pustaka Setia.

Umesao, Tadao et.al. 1992. Nihongo Daijiten. Tokyo: Koudansha.

Wiyadi, Alberths et.al.1995. Kamus Besar Bahasa Indonesia. Jakarta:

Balai Pustaka. 